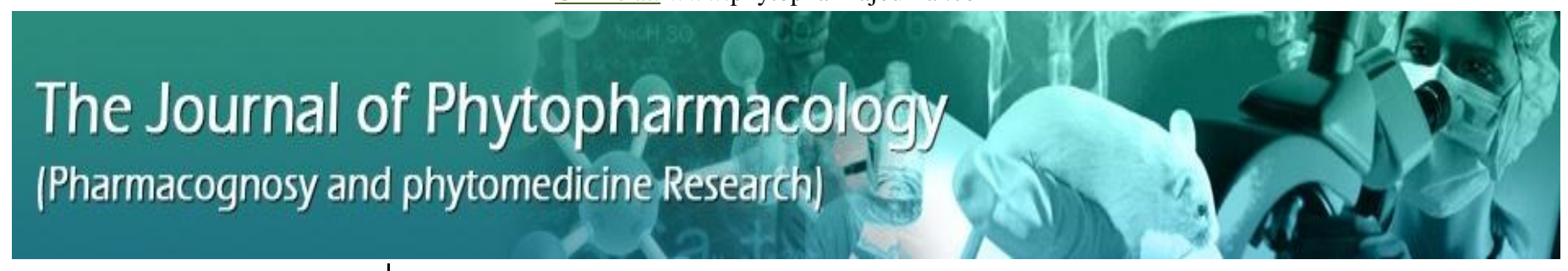

Research Article

ISSN 2230-480X

JPHYTO 2015; 4(4): 212-216

July- August

(C) 2015, All rights reserved

Manivannan R

Assistant Professor, Department of Chemistry, Government Arts College (Autonomous), Kumbakonam-612001, Tamilnadu, India

Aeganathan R.

Research Scholar, Department of Chemistry, Government Arts College (Autonomous), Kumbakonam-612001, Tamilnadu, India

Prabakaran K.

Research Scholar, Department of Chemistry, Government Arts College (Autonomous), Kumbakonam-612001, Tamilnadu, India

Correspondence:

Manivannan R

Assistant Professor, Department of Chemistry, Government Arts College (Autonomous), Kumbakonam-612001, Tamilnadu, India

Email:

manickam_mani@yahoo.co.in

\section{Anti-microbial and anti-inflammatory flavonoid constituents from the leaves of Lawsonia inermis}

\author{
Manivannan R*., Aeganathan R., Prabakaran K.
}

\section{ABSTRACT}

A chemical investigation on the leaves of Lawsonia inermis led to the isolation and identification of five known and rare flavonoids, apigenin (1), 5, 7, 4' - trihydroxy-6, 3', 5'-trimethoxyflavone (2), pectolinarigenin (3), apigenin-7-O- $\beta$-D-glucoside (4), and pectolinarin (5). Their structures were established on the basis of chromatography and spectroscopic evidence and comparisons with literature data. Antimicrobial and carrageenan induced paw edema in male albino rats were determined. Compounds 4 and 5 showed the most powerful antimicrobial effect against Escherichia coli and Aspergillus flavus at the dose of $200 \mathrm{mg} / \mathrm{kg}$. Compound 2 showed pronounced anti-inflammatory effects $(3.17 \pm 0.15$ after $3 \mathrm{~h}$ of injection), slightly higher than that of other four compounds.

Keywords: Lawsonia inermis, Flavonoids, Antimicrobial, Anti-inflammatory activity.

\section{INTRODUCTION}

Flavonoids have recently considerable interest because of their potential beneficial effects on human health ${ }^{[1]}$. Their occurrence is therefore widespread in the plant kingdom and about 500 types of flavonoids are known ${ }^{[2]}$. The searches for new biologically active compounds are most often based on hints coming from ethnobotany but there are still a huge number of unstudied plants. Plants are now considered as a valuable source of unique natural products for the development of medicines against various diseases and also for the development of industrial products. The present study describes the isolation and structure elucidations of five flavonoids obtained for the first time from the leaves of Lawsonia inermis. The known flavonoids: apigenin (1), 5, 7, 4'-trihydroxy-6, 3', 5'-trimethoxyflavone (2), pectolinarigenin (3), apigenin-7-O- $\beta$-D-glucoside (4), pectolinarin (5) were identified by spectroscopic evidences and by comparison with literature data previously reported.

Lawsonia inermis is a much branched glabrous shrub or small tree, cultivated for its leaves although stem bark, roots, flowers and seeds are also used in traditional medicine. The plant is reported to contain flavonoids, tannins, alkaloids, terpenoids and quinones, and reported to have analgesic, hypoglycemic, anti-inflammatory, antimicrobial, antioxidant, antifertility, and anticancer properties ${ }^{[3]}$. Based on these aspects we have studied the phytochemical constituents from the leaves of $L$. inermis and their antimicrobial and anti-inflammatory activities in a carrageenan induced paw edema bioassay in male albino rats.

\section{MATERIAL AND METHODS}

\section{General experimental procedures}

Melting points were determined on a Fisher Scientific melting point apparatus and are uncorrected. UV spectra were recorded on an ultraviolet spectrophotometer (UV2550, Shimadzu, Japan). IR spectra were measured on FT-IR spectrophotometer (Perkin Elmer, PE 1600, USA) with KBr tablets from 4000 to $400 \mathrm{~cm}^{-1}$ with resolution of $2 \mathrm{~cm}^{-1}$. NMR experiments were performed on a Bruker AMX 400 instrument (Bruker Company, Faelladen, Switzerland) standard pulse sequences running at $400 \mathrm{MHz}$ for ${ }^{1} \mathrm{H}$ NMR and ${ }^{13} \mathrm{C}$ NMR. Chemical shifts are given in $\delta(\mathrm{ppm})$, TMS was used as internal standard material and the coupling constants $(J)$ are given in Hz. Column chromatography $(\mathrm{CC})$ was performed on silica gel 60 as stationary phase (particle size 0.04-0.036 mm, 230-400 mesh, ASTM E. Merck, Germany) and activated by heating at $110{ }^{\circ} \mathrm{C}$ for one hour prior to use. A Shimadzu HPLC system (Columbia, MD), was used with UV detection at $2800-350 \mathrm{~nm}$, with a chromatographic system comprising a Spectra Physics P-200 series gradient pump (Fremont, CA, USA), and a rheodyne injector fitted with a 20-FL loop, a C18 column $(250 \times 4.6 \mathrm{~mm})$ (phenomenex, Torrance, CA, USA) was used. 


\section{Plant material}

The leaves of $L$. inermis were collected from the local area in and around Kumbakonam, Thanjavur District (India) and authenticated by Dr. N. Ramakrishnan, Head \& Associate Professor, Department of Botany, Government Arts College (Autonomous), Kumbakonam, Tamilnadu, India with voucher specimen number GACBOT 501 was deposited at the Herbarium of the Department of Botany, in our institution. The plant leaves were air dried under shade and made into fine powder by using hand homogenizer and sieved through sieve No.40 and the fine powder was for extraction procedure and evaluation.

\section{Extraction and isolation}

The air-dried fresh leaves of L. inermis $(3 \mathrm{Kg})$ were powdered and extracted with $90 \% \mathrm{MeOH}(8 \times 500 \mathrm{ml})$ at room temperature. The $\mathrm{MeOH}$ was evaporated in vacuo to give dark brown syrup (300 g). The syrup was suspended in water and extracted with petroleum ether and EtOAc, successively. The petroleum ether layer was concentrated to give a brown syrup (60.5 g) which was subjected to column chromatography on silica gel (60/230-400 mesh, Merck), and eluted with a gradient of petroleum ether and EtOAc (40:1, 30:1, 20:1) to give $\mathbf{1}(17.8 \mathrm{mg}), \mathbf{2}(16.2 \mathrm{mg}), \mathbf{3}(9.0 \mathrm{mg})$. The EtOAc layer was concentrated to give a brown syrup $(30 \mathrm{~g})$ which was subjected to chromatography on silica gel, and eluted with a gradient of $\mathrm{CHCl}_{3}$ and $\mathrm{MeOH}(40: 1,20: 1 \mathrm{MeOH})$ to give $4(11.7 \mathrm{mg})$ and $5(13.5 \mathrm{mg})$. The concentrated extract was applied to preparative paper chromatography using the solvent systems, $\mathrm{BAW}$ (n-BuOH / AcOH / $\mathrm{H}_{2} \mathrm{O}$ - 4:1:5), 15, $30,60 \% \mathrm{AcOH}$ and then phenol saturated with water.

Apigenin (1): yellow powder; mp. $340-342^{\circ} \mathrm{C} ; \mathrm{R}_{\mathrm{f}}=0.88$; RT: 10.2

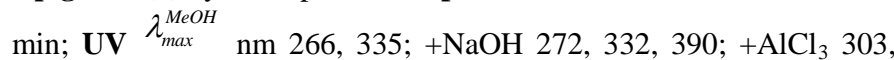
345,$380 ;+\mathrm{AlCl}_{3} / \mathrm{HCl} 298,340,381$; +NaOAc: 274, 304, 378; $+\mathrm{H}_{3} \mathrm{BO}_{3}$ 268, 300, 354. FT-IR: $(\mathrm{KBr}) \mathrm{cm}^{-1} 3289,3090(\mathrm{OH}), 2920$ 1655(C=O), 1611 and $1504(\mathrm{Ar}), 1446,1180,832 ;{ }^{1} \mathbf{H}$ NMR $(400$ MHz, DMSO- $\left.d_{6}\right): \delta 7.90\left(2 \mathrm{H}, \mathrm{d}, J=8.8 \mathrm{~Hz}, \mathrm{H}-2^{\prime}, \mathrm{H}-6^{\prime}\right), 6.91(2 \mathrm{H}, \mathrm{d}$, $\left.J=8.8 \mathrm{~Hz}, \mathrm{H}-3^{\prime}, \mathrm{H}-5^{\prime}\right), 6.79(1 \mathrm{H}, \mathrm{s}, \mathrm{H}-3), 6.46(1 \mathrm{H}, \mathrm{d}, J=1.6 \mathrm{~Hz}, \mathrm{H}-$ 8), $6.19(1 \mathrm{H}, \mathrm{d}, J=1.6 \mathrm{~Hz}, \mathrm{H}-6), 12.94(1 \mathrm{H}, \mathrm{s}, 5-\mathrm{OH}), 10.82$ and 10.36 (each $1 \mathrm{H}, \mathrm{s}, 7-\mathrm{OH}$ and $\left.4^{\prime}-\mathrm{OH}\right) ;{ }^{13} \mathbf{C}$ NMR (400 MHz, $\mathrm{CDCl}_{3}$,): $\delta 182.3$ (C-4), 164.6 (C-2), 163.9 (C-7) , 160.8 (C-9), 159.4 (C-4'), 156.6 (C-5), 127.8 (C-6', C-2'), 120.5 (C-1'), 115.2 (C-3', C-5'), 104.2 (C-10) , 102.4 (C-3), 99.6 (C-6), 95.1 (C-8).

5, 7, 4'-trihydroxy-6, 3', 5'-trimethoxyflavone (2): pale yellow powder; mp. $237-239^{\circ} \mathrm{C} ; \mathrm{R}_{\mathrm{f}}=0.78 ; \mathrm{RT}: 6.4 \mathrm{~min} ; \mathbf{U V} \lambda_{\max }^{\lambda_{\mathrm{MeOH}}} \mathrm{nm} \mathrm{275}$, 352; FT-IR: $(\mathrm{KBr}) \mathrm{cm}^{-1} 3452(\mathrm{OH}), 1654(\mathrm{C}=\mathrm{O}), 1602,1522$ and 1473 (Ar), 1364, 1172, 1010, 831; ${ }^{1} \mathbf{H}$ NMR (400 MHz,DMSO- $\left.d_{6}\right): \delta$ $7.15\left(2 \mathrm{H}, \mathrm{d}, J=2.0 \mathrm{~Hz}, \mathrm{H}-2^{\prime}, \mathrm{H}-6^{\prime}\right), 6.95(1 \mathrm{H}, \mathrm{s}, \mathrm{H}-3), 6.62(1 \mathrm{H}, \mathrm{s}, \mathrm{H}-$ 8), 3.74, 3.77 (each $\left.3 \mathrm{H}, \mathrm{s}, 3^{\prime}, 5^{\prime}-\mathrm{OCH}_{3}\right), 3.88\left(3 \mathrm{H}, \mathrm{s}, 6-\mathrm{OCH}_{3}\right), 12.98$ $(1 \mathrm{H}, \mathrm{s}, 5-\mathrm{OH}), 10.81(1 \mathrm{H}, \mathrm{s}, 7-\mathrm{OH}), 9.69\left(1 \mathrm{H}, \mathrm{s}, 4^{\prime}-\mathrm{OH}\right) ;{ }^{13} \mathbf{C} \mathbf{~ N M R}$ (400 MHz, $\mathrm{CDCl}_{3}$,): $\delta 181.9(\mathrm{C}-4) ; 163.4(\mathrm{C}-2) ; 159.5$ (C-7); 154.1 (C-9); 153.6 (C-5); 152.1 (C-2'); 159.9 (C- 4'); $118.1\left(\mathrm{C}-5^{\prime}\right) ; 112.3$ (C-6'); 107.8 (C-3); 106.9 (C-1'); 105.6 (C-10); 116.9 (C-3'); 142.4 (C-6); $91.8(\mathrm{C}-8) ; 61.2\left(\mathrm{OCH}_{3}\right) ; 57.6\left(\mathrm{OCH}_{3}\right) ; 57.1\left(\mathrm{OCH}_{3}\right)$.

Pectolinarigenin (3): yellow needles; mp. $216-218^{\circ} \mathrm{C}$; $\mathrm{R}_{\mathrm{f}}=0.92$; RT:

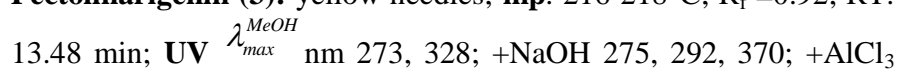
280, 303, 352; $+\mathrm{AlCl}_{3} / \mathrm{HCl} \mathrm{278,} \mathrm{378;} \mathrm{+NaOAc} \mathrm{278,} \mathrm{295,} \mathrm{370;}$ $+\mathrm{H}_{3} \mathrm{BO}_{3}$ 264, 340. FT-IR: $(\mathrm{KBr}) \mathrm{cm}^{-1} 3292(\mathrm{OH}), 1651(\mathrm{C}=\mathrm{O}), 1595$ and $1504(\mathrm{Ar}) ;{ }^{1} \mathbf{H}$ NMR (400 MHz, DMSO- $\left.d_{6}\right): \delta 8.07(2 \mathrm{H}, \mathrm{d}, J=$ $\left.8.6 \mathrm{~Hz}, \mathrm{H}-2^{\prime}, \mathrm{H}-6^{\prime}\right), 7.10$ (2H, d, J = 8.8 Hz, H-3', H-5'), 6.89 (1H, s, $3-\mathrm{H}), 6.60(1 \mathrm{H}, \mathrm{s}, \mathrm{H}-8), 3.74,3.85$ (each $3 \mathrm{H}, \mathrm{s}, 4^{\prime}-\mathrm{OCH} 3$ and 6$\left.\mathrm{OCH}_{3}\right) ;{ }^{13} \mathbf{C}$ NMR $\left(400 \mathrm{MHz}, \mathrm{CDCl}_{3}\right): 61.2\left(\mathrm{OCH}_{3}\right), 54.6\left(\mathrm{OCH}_{3}\right), \delta$ 162.6 (C-2), 104.7 (C-3), 184.2 (C-4), 151.9 (C-5), 133.2 (C-6), 158.1 (C-7), 93.4 (C-8), 153.7 (C-9), 104.2 (C-10), 121.8 (C-1'), 128.1 (C2', C-6'), 112.1 (C-3', C-5'), $160.1\left(\mathrm{C}-4^{\prime}\right)$.
Apigenin-7-O-B-D-glucoside (4): pale yellow solid crystal; m.p. 239-

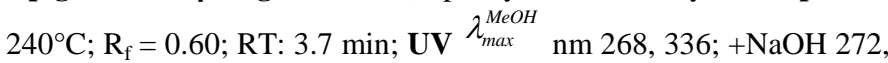
$384,+\mathrm{AlCl}_{3}$ 276, 340, 365; $+\mathrm{AlCl}_{3} / \mathrm{HCl} 277,343$; +NaOAc 266, 392; $+\mathrm{H}_{3} \mathrm{BO}_{3}$ 267, 348. FT-IR: (KBr) cm $\mathrm{cm}^{-1} 3405,2920,2848,1738,1630$, 598. ${ }^{1} \mathbf{H}$ NMR $\left(400 \mathrm{MHz}, \mathrm{DMSO}-d_{6}\right): \delta 7.96(2 \mathrm{H}, \mathrm{d}, \mathrm{J}=8.9 \mathrm{~Hz}, \mathrm{H}-6$ ', H-2'), 6.95 (2H, d, J = 8.9 Hz, H-5', H-3'), $6.90(1 \mathrm{H}, \mathrm{s}, \mathrm{H}-3), 6.82(1 \mathrm{H}$, $\mathrm{d}, J=2.1 \mathrm{~Hz}, \mathrm{H}-8), 6.42(1 \mathrm{H}, \mathrm{d}, J=2.1 \mathrm{~Hz}, \mathrm{H}-6), 5.06(1 \mathrm{H}, \mathrm{d}, J=7.2$ Hz, H-1" Glc), 3.17 (1H, d, H-2"), 3.23 (1H, d, H-3"), $3.13(1 \mathrm{H}, \mathrm{d}$, H-4"), $3.56\left(1 \mathrm{H}, \mathrm{t}, \mathrm{H}-5^{\prime \prime}\right), 3.58\left(1 \mathrm{H}, \mathrm{dd}, \mathrm{J}=11.5,4.9 \mathrm{~Hz}, \mathrm{H}_{\mathrm{a}}-6, \mathrm{Glc}\right)$, $3.84\left(1 \mathrm{H}, \mathrm{dd}, J=11.5,2.5 \mathrm{~Hz}, \mathrm{H}_{\mathrm{b}}-6, \mathrm{Glc}\right), 9.42\left(1 \mathrm{H}, \mathrm{s}, 4{ }^{4}-\mathrm{OH}\right) ;{ }^{13} \mathrm{C}$ NMR (400 MHz, $\mathrm{CDCl}_{3}$ ): 181.4 (C-4), 164.6 (C-2), 102.2 (C-3), 161.6 (C-5), 99.2 (C-6), 162.5 (C-7), 94.7 (C-8), 156.4 (C-9), 105.8 (C-10), $121.3\left(\mathrm{C}-1^{\prime}\right), 128.9$ (C-2'), 115.4 (C-3'), 161.9 (C-4'), 115.3 $\left(\mathrm{C}-5^{\prime}\right), 128.1\left(\mathrm{C}-6^{\prime}\right), 99.7\left(\mathrm{C}-1^{\prime \prime}\right), 73.3\left(\mathrm{C}-2^{\prime \prime}\right), 75.7$ (C-3"), 69.9 (C$\left.4^{\prime \prime}\right), 77.4\left(\mathrm{C}-5^{\prime \prime}\right), 64.8$ (C-6").

Pectolinarin (5): yellow needles; m.p. $260-262^{\circ} \mathrm{C} ; \mathrm{R}_{\mathrm{f}}=0.74$; RT:

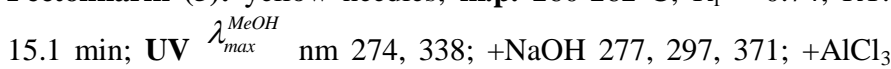
284, 302, 353; $+\mathrm{AlCl}_{3} / \mathrm{HCl} \mathrm{279,377;+NaOAc} \mathrm{274,} \mathrm{296,} \mathrm{371;}$ $+\mathrm{H}_{3} \mathrm{BO}_{3}$ 265, 338. FT-IR: (KBR) cm $\mathrm{cm}^{-1} 3395(\mathrm{OH}), 1665,1620,1604$, $1510 ;{ }^{1}$ H-NMR $\left(400 \mathrm{MHz}, \mathrm{DMSO}-d_{6}\right): \delta 1.16(3 \mathrm{H}, \mathrm{d}, J=6.3 \mathrm{~Hz}, \mathrm{H}-$ $\left.6^{\prime \prime \prime}\right), 3.64\left(1 \mathrm{H}, \mathrm{dd}, J=11.5,4.9 \mathrm{~Hz}, \mathrm{H}_{\mathrm{a}}-6^{\prime \prime}\right), 3.72\left(3 \mathrm{H}, \mathrm{s}, 4-\mathrm{OCH}_{3}\right)$, $3.78\left(1 \mathrm{H}, \mathrm{dd}, J=11.5,2.5 \mathrm{~Hz}, \mathrm{H}_{\mathrm{b}}-6^{\prime \prime}\right), 4.01\left(3 \mathrm{H}, \mathrm{s}, 6-\mathrm{OCH}_{3}\right), 4.53$ (1H, s, H-1"'), 3.65 (1H, s, H-2'"'), $3.46\left(1 \mathrm{H}, \mathrm{dd}, \mathrm{H}-3^{\prime \prime \prime}\right), 3.30(1 \mathrm{H}, \mathrm{dd}$, H-4"'), $3.40\left(1 \mathrm{H}, \mathrm{m}, \mathrm{H}-5^{\prime \prime \prime}\right), 5.68\left(1 \mathrm{H}, \mathrm{d}, J=7.3 \mathrm{~Hz}, \mathrm{H}-1^{\prime \prime}\right), 3.19(1 \mathrm{H}$, d, H-2"), $3.26\left(1 \mathrm{H}, \mathrm{d}, \mathrm{H}-3^{\prime \prime}\right), 3.12\left(1 \mathrm{H}, \mathrm{d}, \mathrm{H}-4^{\prime \prime}\right), 6.81(1 \mathrm{H}, \mathrm{s}, \mathrm{H}-3)$, $7.22\left(2 \mathrm{H}, \mathrm{d}, J=9.0 \mathrm{~Hz}, \mathrm{H}-3^{\prime}\right.$ and $\left.\mathrm{H}-5^{\prime}\right), 7.34(1 \mathrm{H}, \mathrm{s}, \mathrm{H}-8), 8.01(2 \mathrm{H}$, $\mathrm{d}, J=9.0 \mathrm{~Hz}, \mathrm{H}-2^{\prime}$ and $\left.\mathrm{H}-6^{\prime}\right), 12.80(1 \mathrm{H}, \mathrm{s}, 5-\mathrm{OH}), 5.37\left(1 \mathrm{H}, \mathrm{s}, 2^{\prime \prime}-\right.$ $\mathrm{OH}), 5.21\left(1 \mathrm{H}, \mathrm{s}, 3^{\prime \prime}-\mathrm{OH}\right), 5.17\left(1 \mathrm{H}, \mathrm{s}, 4^{\prime \prime}-\mathrm{OH}\right), 4.65\left(1 \mathrm{H}, \mathrm{s}, 2^{\prime \prime \prime}-\mathrm{OH}\right)$, $4.52\left(1 \mathrm{H}, \mathrm{d}, 3^{\prime \prime \prime}-\mathrm{OH}\right), 4.70\left(1 \mathrm{H}, \mathrm{s}, 4^{\prime \prime \prime}-\mathrm{OH}\right) ;{ }^{13} \mathbf{C}$ NMR $(400 \mathrm{MHz}$, $\left.\mathrm{CDCl}_{3}\right): 54.6\left(\mathrm{OCH}_{3}\right), 61.2\left(\mathrm{OCH}_{3}\right), 163.6(\mathrm{C}-2), 104.0(\mathrm{C}-3), 183.7$ (C-4), 154.2 (C-5), 133.1 C-6), 157.2 (C-7), 96.4 (C-8), 153.7 (C-9), 106.8 (C-10), 122.9 (C-1'), 129.2 (C-2', C-6'), 114.9 (C-3', C-5'), $162.2\left(\mathrm{C}-4^{\prime}\right), 102.8\left(\mathrm{C}-1^{\prime \prime}\right), 75.1\left(\mathrm{C}-2^{\prime \prime}\right), 77.8\left(\mathrm{C}-3^{\prime \prime}\right), 70.7$ (C-4"), 77.1 $\left(\mathrm{C}-5^{\prime \prime}\right), 67.9\left(\mathrm{C}-6^{\prime \prime}\right), 101.7$ (C-1"'), $72.6\left(\mathrm{C}-2^{\prime \prime \prime}\right), 73.2\left(\mathrm{C}-3^{\prime \prime}\right), 74.2$ (C$\left.4^{\prime \prime \prime}\right), 69.7$ (C-5"'), 18.8 (C-6"').

\section{Anti-microbial activity}

Anti-microbial activity test was carried out with the following modification of the method originally described by Bauer et al., ${ }^{[4]}$. Muller Hinton agar was prepared and autoclaved at $15 \mathrm{lbs}$ pressure for $20 \mathrm{~min}$ and cooled to $45^{\circ} \mathrm{C}$. The cooled media was poured on to sterile petriplates and allowed for solidification. The plates with media were seeded with the respective microbial suspension using sterile swab. The isolated compound prepared at different dose individually was placed on each petriplates discs along with the control and standard (streptomycin and amphotericin) discs. The plates were incubated at $37^{\circ} \mathrm{C}$ for $24 \mathrm{~h}$. After incubation period, the diameter of the inhibition zone around the paper disc was measured and reported in millimeters.

\section{Anti-inflammatory activity}

\section{Carrageenan induced rat paw edema}

The anti-inflammatory activity of the test compounds was evaluated in Wistar rats following a method published in the literature ${ }^{[5]}$. The different test concentrations at the dose of 100 and $200 \mathrm{mg} / \mathrm{kg}$ of isolated compounds and $300 \mathrm{mg} / \mathrm{kg}$ of methanol extracts were administrated to the animals in the test groups by oral route. Animals in the standard group received Diclofenac sodium at dose of 100 $\mathrm{mg} / \mathrm{kg}$, by oral route. Control group animals received $2 \%$ DMSO at the dose of $10 \mathrm{ml} / \mathrm{kg}$ body weight. The acute inflammation was induced by the sub-plantar administration of $0.1 \mathrm{ml}$ of $2 \%$ carrageenan in the right paw. Paw volume was measured by using digital plethysmometer (Ugo Basile-Italy) before administration of carrageenan and after 1,2 , and $3 \mathrm{~h}$ intervals ${ }^{[6]}$. The efficacy of the different drugs was tested on its ability to inhibit paw edema as compared to control group. 
Volume of edema = Final Paw Volume - Initial Paw Volume

The Percentage inhibition of paw edema was calculated by the formula as below.

$$
\% \text { Inhibition of Paw edema }=[(\mathrm{VC}-\mathrm{VT}) / \mathrm{VC}] \mathrm{X} 100
$$

Where, $\mathrm{VC}=$ Paw edema of control group and VT = Paw edema of treated group

\section{Experimental animals}

Male albino rats (150-200 g) were used in the study. They housed in cages and maintained under standard conditions at $26 \pm 2^{\circ} \mathrm{C}$ and relative humidity $44-56 \%$ and $10 \mathrm{~h}$ light and $14 \mathrm{~h}$ dark cycles each day for one week before and during the experiments. All animals were fed with standard rodent pellet diet, and water adlibitum. Before starting the experiment on animals, the experimental protocol was subjected to the scrutiny of the Institutional Animal Ethics Committee (IAEC), Bharathidasan University, Trichirappalli, Tamilnadu, India (Approval No. BDU/IAEC/2011/31/29.03.2011).

The animals were divided into 13 groups each group containing six rats.

Group - I: Served as control, received the vehicle only (2\%) carrageenan (10 $\mathrm{mg} / \mathrm{kg}$ ).

Group-II: Served as standard, received Diclofenac sodium at dose of 100 $\mathrm{mg} / \mathrm{kg}$.

Group-III to VII: Served as test, received compounds (1-5) isolated from the leaves of $L$. inermis at doses of $100 \mathrm{mg} / \mathrm{kg}$ respectively.
Group-VIII to XII: Served as test, received compounds (1-5) isolated from the leaves of $L$. inermis at doses of $200 \mathrm{mg} / \mathrm{kg}$ respectively.

Group-XIII: Served as test, received methanol extract of $L$. inermis at doses of $300 \mathrm{mg} / \mathrm{kg}$ respectively.

\section{Statistical analysis}

The experimental results were expressed as statistical comparisons of mean \pm SEM which were carried out by one way analysis of variance (ANOVA) followed by Dunnet Multiple Comparisons Test. P values less than 0.05 was considered as statistically significant

\section{RESULTS AND DISCUSSION}

\section{Chemical constituents}

In this paper, we report the isolation of five known flavonoids using column chromatography techniques from leaves of $L$. inermis being these apigenin (1), 5, 7, 4'-trihydroxy-6, 3', 5'-trimethoxyflavone (2), pectolinarigenin (3), apigenin-7- $O-\beta-\mathrm{D}$-glucoside (4), pectolinarin (5). All isolated compounds 1-5 (Figure 1), are soluble in methanol and when dissolved in dilute alkali gave an intense yellow solution, as well as, positive reaction with $\mathrm{FeCl}_{3}{ }^{[7]}$. The structures of the isolated compounds were established by melting point, $R_{f}$ chromatographic behavior and by means of UV, IR, and NMR spectral analysis. The IR spectrum of compounds (1 - 5) showed absorption bands corresponding to hydroxyl $\left(3350 \mathrm{~cm}^{-1}\right)$, carbonyl $\left(1650 \mathrm{~cm}^{-1}\right)$, and aromatic $\left(1600,1500 \mathrm{~cm}^{-1}\right)$ groups.<smiles>O=c1cc(-c2ccc(O)cc2)oc2cc(O)cc(O)c12</smiles>

(1)<smiles>COc1cc(-c2cc(=O)c3c(O)c(OC)c(O)cc3o2)cc(OC)c1O</smiles>

(2)<smiles>COc1ccc(-c2cc(=O)c3c(O)c(OC)c(O)cc3o2)cc1</smiles>

(3)<smiles>O=c1cc(-c2ccc(O)cc2)oc2cc(OC3OC(O)C(O)C(O)C3O)cc(O)c12</smiles>

(4)

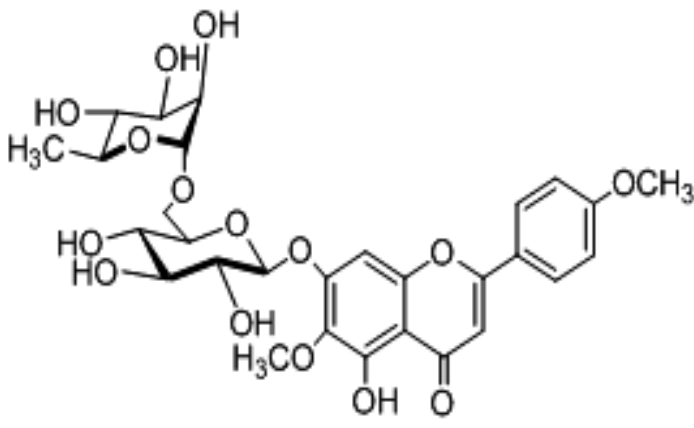

(5)

Figure 1 Compounds 1-5 isolated from leaves of L. inermis.

Compound 1 was isolated as a yellow solid; $\mathrm{mp:} 340-342^{\circ} \mathrm{C}$. The UV spectrum $\lambda_{\max }(\mathrm{MeOH})$ showed bands at 266 and $335 \mathrm{~nm}(\mathrm{sh})$, deducing its flavone nature ${ }^{[8]}$. This compound showed bathochromic shifts with sodium methoxide and aluminum chloride respectively, at band I and bathochromic shift at band II with sodium acetate, giving indication for free hydroxyl groups at C-4', C-5 and C-7. The ${ }^{13} \mathrm{C}$ NMR spectrum was quite informative, indicating the presence of 15 carbon signals and the ${ }^{1} \mathrm{H}$ NMR spectrum of compound $\mathbf{1}$ was consistent with a flavone structure and it exhibited a characteristic $\mathrm{AA}^{\prime} \mathrm{BB}^{\prime}$ resonance system with the aromatic protons $\mathrm{H}-2^{\prime}$ and $\mathrm{H}-6^{\prime}$ $(\delta 7.90, \mathrm{~d}, 8.8)$ and $\mathrm{H}-3^{\prime}$ and $\mathrm{H}-5^{\prime}(\delta 6.91, \mathrm{~d}, 8.8)$, and signals for $\mathrm{H}-8$ and H-6 $(\delta 6.46,6.19)$. The spectral data of compound 1 were in good agreement with those reported for 4', 5, 7- trihydroxyflavanone (apigenin) ${ }^{[9,10]}$. 
Compound 2 obtained as a pale yellow powder, mp: $237-239^{\circ} \mathrm{C}$; the UV spectrum $\lambda_{\max }(\mathrm{MeOH})$ showed bands at 275 and $352 \mathrm{~nm}$ (sh) and also with diagnostic reagents such as $\mathrm{NaOAc}$ and $\mathrm{AlCl}_{3}$ indicated the presence of the free 5- and 7-hydroxyl groups. The ${ }^{1} \mathrm{H}$ NMR spectrum exhibited three singlets at $\delta 3.88(3 \mathrm{H}), 3.77(3 \mathrm{H})$ and $3.74(3 \mathrm{H})$, while the ${ }^{13} \mathrm{C}$ NMR spectrum showed signals at $\delta 61.2,57.6$ and 57.1, proving the existence of three methoxy groups. The ${ }^{1} \mathrm{H}$ NMR showed a multiplet signal at $\delta 7.15$, corresponding to two aromatic protons, which were assigned to $\mathrm{H}-6^{\prime}$ and $\mathrm{H}-2^{\prime}$ in ring $\mathrm{B}$ and three hydroxyl protons were observed at $\delta 12.98,10.81$ and 9.69 as singlets and they could be assigned to $5-\mathrm{OH}, 7-\mathrm{OH}$ and 4 '-OH respectively which confirmed the UV data. The position of the methoxy groups signals at $\delta 3.88,3.74$ and 3.77 with carbon signals at $\delta 142.4$ (C-6), $\delta$ $116.9\left(\mathrm{C}-3^{\prime}\right)$ and $118.1\left(\mathrm{C}-5^{\prime}\right)$ were determined by the ${ }^{1} \mathrm{H}$ and ${ }^{13} \mathrm{C}$ NMR spectra. The structure of compound 2 was deduced as $5,7,4^{\prime}$ trihydroxy-6, 3', 5'-trimethoxyflavone which was confirmed by comparison of its spectral data with those in the literature ${ }^{[11]}$.

Compound 3 obtained as yellow needles, mp: $216-218{ }^{\circ} \mathrm{C}$; the UV spectral behavior of $\mathbf{3}$ with diagnostic reagents, such as NaOAc and $\mathrm{AlCl}_{3}$ indicated the presence of the free 5- and 7-hydroxyl groups. The ${ }^{1} \mathrm{H}$ NMR spectrum showed an $\mathrm{AA}^{\prime} \mathrm{BB}^{\prime}$ system at $\delta 6.94$ and 7.77 (each $2 \mathrm{H}, J=9.0 \mathrm{~Hz}$ ) due to a $4^{\prime}$-oxygenated B ring ${ }^{[10]}$. The presence of methoxy groups was deduced by carbon resonances at $\delta 160.1$ and 133.2 (C4'and C6) in the ${ }^{13} \mathrm{C}$ NMR spectrum. Thus, the structure of 3 was deduced as pectolinarigenin and confirmed by comparison of its spectral data with those in the literature ${ }^{[12]}$.

Compound 4 was isolated as a pale yellow amorphous solid; mp: 239$240^{\circ} \mathrm{C}$. The UV spectrum $\lambda_{\max }(\mathrm{MeOH})$ showed bands at 268 and 336 $\mathrm{nm}$ (sh), deducing its flavone nature. This compound also gave positive color reactions for a hydroxyl flavone with several reagents ${ }^{[13]}$. The UV spectral data obtained in solution with methanol indicated that $\mathbf{4}$ was a flavone glycoside, while on addition of $\mathrm{NaOAc}$ indicated the $7^{\text {th }}$ position to be occupied. Addition of $\mathrm{H}_{3} \mathrm{BO}_{3}$ indicated the presence of catecholic hydroxyl groups. Addition of $\mathrm{AlCl}_{3}$ indicating the presence of free hydroxyl at $\mathrm{C}-5$. The ${ }^{1} \mathrm{H}$ and ${ }^{13} \mathrm{C}$ NMR spectra were almost identical to those of $\mathbf{1}$. In the ${ }^{1} \mathrm{H}$ NMR spectrum of $\mathbf{4}$, the aromatic proton signals of two doublets at 6.82 and $6.42(J=2.1 \mathrm{~Hz}$, $1 \mathrm{H}$ each) were attributed to $\mathrm{H}-8$ and $\mathrm{H}-6$ of ring A, respectively. Two vicinal coupled doublets at $\delta 7.96$ and $6.95(J=8.8 \mathrm{~Hz}, 2 \mathrm{H}$ each $)$ were assigned to $\mathrm{H}-2^{\prime} / \mathrm{H}-6^{\prime}$ and $\mathrm{H}-3^{\prime} / \mathrm{H}-5^{\prime}$, respectively, of ring $\mathrm{B}$. Additionally, a singlet at $\delta 6.90$ was ascribed to H-3. Additional resonances arising from a D-glucose unit in particular for the anomeric proton at $\mathrm{H}-1^{\prime \prime}(\delta 5.06,1 \mathrm{H}, \mathrm{d}, J=7.2 \mathrm{~Hz}$, ) and in the range $\delta$ 3.17-3.49, were observed in the ${ }^{1} \mathrm{H}$ NMR data of 4 . The glucose moiety was allocated at $\delta 162.5$ was attributed to $\mathrm{C}-7$ based on ${ }^{13} \mathrm{C}$ NMR data compared to those published in the literature $(8-10,14)$. Acid hydrolysis of $\mathbf{4}$ yielded the aglycone apigenin (1).

Compound 5 was isolated as yellow needles; m.p: $260-262^{\circ} \mathrm{C}$; the UV spectrum $\lambda_{\max }(\mathrm{MeOH})$ showed bands at 274 and $338 \mathrm{~nm}(\mathrm{sh})$, deducing its flavone nature. Upon addition of sodium methoxide, the UV spectrum showed a shift indicating the presence of a free hydroxyl group at $\mathrm{C}-5$, while, the bathochromic shift with aluminum chloride confirmed the existence of 5-OH group. On the other hand, the absence of the shift with sodium acetate indicated the attachment of a sugar residue at C-7. The NMR signals of $\mathbf{5}$ were similar to those of 3. The only difference was the appearance of additional signals for two sugar residues. The first sugar fragment corresponded to a glycosyl and the second one to a rhamnosyl. Also three of the six hydroxyl groups could be assigned to $2^{\prime \prime}-\mathrm{OH}, 3^{\prime \prime}-\mathrm{OH}$ and 4 "'-OH at $\delta$ $5.37,5.21$ and 5.17 respectively in the glycosyl moiety. Similarly the other three hydroxyl group signals were assigned to $2^{\prime \prime \prime}-\mathrm{OH}, 3$ "''-OH and $4 " \prime \prime-O H$ at $\delta 4.65,4.52$ and 4.70 respectively in the rhamnosyl moiety. Acid hydrolysis of $\mathbf{5}$ yielded the aglycone pectolinarigenin (3). From these data the structure of compound $\mathbf{5}$ was unambiguously identified as pectolinarin and also confirmed by comparison of its spectral data with those in the literature ${ }^{[12,15]}$.

In the literature $L$. inermis has been reported to contain active compounds with different biological activities based on their use in traditional medicine. In the world there has been a revival of interest in herbal medicines as a result of increased awareness of the limited availability of synthetic pharmaceutical products to control major diseases, in addition to their higher incidence of adverse reactions compared to plant preparations. Therefore, it was deemed of interest to carry out certain pharmacological tests, such as antimicrobial and anti-inflammatory of the total plant extract and its successive fractions.

\section{Anti-microbial Activity}

The anti-microbial activity tests were carried out on $\mathrm{MeOH}$ extract and five isolated flavonoids from $L$. inermis using the disk diffusion method against Gram positive and Gram-negative bacteria. The diffusion test was applied to six microorganisms including three types of bacterial and three types of fungi namely Escherichia coli, Staphylococcus aureus, Klebsella pneumonia, Aspergillus niger, Aspergillus flavus and Candida albicans were chosen to investigate the anti-microbial capacity of $L$. inermis. The treated Petri disks were kept at $4{ }^{\circ} \mathrm{C}$ for $1 \mathrm{~h}$, and incubated at $37{ }^{\circ} \mathrm{C}$ for $24 \mathrm{~h}$. The antimicrobial activity was assessed by measuring the zone of growth inhibition surrounding the disks. Each experiment was carried out in triplicate. The results summarized in Table 1 showed that the crude extract from $L$. inermis as well as compounds 1-5 prevented the growth of all the tested microorganisms and it has been revealed that the medium diameter of inhibition zone increases proportionally with the increase of flavonoids concentration. The minimum inhibitory concentration is a measure to define the anti-microbial activity of an organism and is defined as the lowest concentration of drug that inhibits visible growth. Careful examination of the antimicrobial activity of the five compounds and the $\mathrm{MeOH}$ crude extract of $L$. inermis revealed that compounds $\mathbf{4}$ and $\mathbf{5}$ inhibited the growth of all microorganisms especially against Escherichia coli, Staphylococcus aureus and Aspergillus flavus in which a better inhibition was noticed than over Aspergillus niger. On the other hand, compounds 1-3 showed less inhibitory activity against the treated microorganisms and fungi. Some flavonoids are formed as antimicrobial barriers in plants in response to microbial infection. There has been an enormous increase in the number of studies on flavonoids as potential antimicrobial agents ${ }^{[16]}$.

Table 1: Anti-microbial activity of flavonoids isolated from L. inermis

\begin{tabular}{|c|c|c|c|c|c|c|c|c|c|c|c|c|}
\hline \multirow{5}{*}{ Microorganisms } & \multicolumn{12}{|c|}{ Zone of inhibition in $\mathrm{mm}$} \\
\hline & & & & & Con & & & & & & \multirow{4}{*}{$\begin{array}{r}\begin{array}{r}\text { Methano } \\
\text { extract }\end{array} \\
100 \mu \mathrm{g}\end{array}$} & \multirow{4}{*}{ Standard } \\
\hline & \multicolumn{2}{|c|}{1} & \multicolumn{2}{|c|}{2} & \multicolumn{2}{|c|}{3} & \multicolumn{2}{|c|}{4} & \multicolumn{2}{|c|}{5} & & \\
\hline & 50 & 100 & 50 & 100 & 50 & 100 & 50 & 100 & 50 & 100 & & \\
\hline & $\mu \mathrm{g}$ & $\mu \mathrm{g}$ & $\mu \mathrm{g}$ & $\mu \mathrm{g}$ & $\mu \mathrm{g}$ & $\mu \mathrm{g}$ & $\mu \mathrm{g}$ & $\mu \mathrm{g}$ & $\mu \mathrm{g}$ & $\mu \mathrm{g}$ & & \\
\hline Staphylococcus aureus & 06 & 09 & 04 & 07 & 08 & 11 & 15 & 21 & 18 & 24 & 13 & $30 *$ \\
\hline Escherichia coli & 08 & 10 & 06 & 09 & 10 & 14 & 20 & 25 & 22 & 27 & 16 & $31 *$ \\
\hline Klebsella pneumonia & 01 & 03 & - & - & 01 & 03 & 04 & 07 & 05 & 08 & 02 & $30 *$ \\
\hline Aspergillus niger & 03 & 05 & 02 & 03 & 04 & 06 & 07 & 09 & 08 & 10 & 06 & $14 * *$ \\
\hline Aspergillus flavus & 02 & 04 & 01 & 02 & 03 & 06 & 08 & 11 & 09 & 12 & 07 & $14 * *$ \\
\hline Candida albicans & - & 02 & - & - & 02 & 04 & 03 & 06 & 04 & 07 & 03 & $14 * *$ \\
\hline
\end{tabular}

Bacteria Standard* - Streptomycin $(100 \mu \mathrm{g})$; Fungal Standard** - Amphotericin - B (20 $\mu \mathrm{g})$ 


\section{Anti-inflammatory Activity}

In order to evaluate the anti-inflammatory activities of $\mathrm{MeOH}$ crude extract and flavonoids isolated from the leaves of $L$. inermis, the carrageenan-induced paw edema was carried out on male albino rats weighing (150-200 g). All rats were fed with the standard rodent pellet diet and water adlibitum. Edema was induced by injecting 0.2 $\mathrm{ml}$ of $2 \%$ carrageenan solution to 13 groups (six animals each) of rat hind paws. All groups showed a decrease in the thickness of edema of the hind paw in different percentages compared to the control group as indicated in (Table 2). The drug isolated from the leaves of $L$. inermis showed significant anti-inflammatory activity, when compared with the control, and a high rate of action against inflammation.

During the study of anti-inflammatory efficacy of $\mathrm{MeOH}$ crude extract and isolated flavonoids using carrageenan induced rat paw edema method, it was quite evident that, a gradual increase in paw volume was observed after carrageenan administration, which reached maximum at 3 hours as compared to control group. There were no significant differences in paw edema volume when standard was observed along with isolated flavonoids with $200 \mathrm{mg} / \mathrm{kg}$ dose level. The standard drug diclofenac sodium at a dose of $100 \mathrm{mg} / \mathrm{kg}$ inhibited the development of edema significantly from $1 \mathrm{~h}$ onwards. It showed maximum reduction $(3.10 \pm 0.10)$ in paw edema at $3 \mathrm{~h}$. It was found that isolated flavonoids at the dose of 100 and $200 \mathrm{mg} / \mathrm{kg}$ showed significant activity at $3 \mathrm{~h}$. Methanol extract at the dose of $300 \mathrm{mg} / \mathrm{kg}$ body weight showed inhibition of paw edema at $3 \mathrm{~h}$ of $3.43 \pm 0.15$. Among the five isolated flavonoids, at the same dose of $200 \mathrm{mg} / \mathrm{kg}$, compound $\mathbf{2}$ showed pronounced anti-inflammatory effect of $3.17 \pm 0.15$ after $3 \mathrm{~h}$ of injection. Compound $\mathbf{1}$ and $\mathbf{3}$ showed to inhibit the induced inflammatory response to carrageenan to a lesser extent than compound $\mathbf{2}$. On the other hand, compounds $\mathbf{4}$ and $\mathbf{5}$ showed to be less potent as anti-inflammatory since they inhibited carrageenaninduced inflammatory by $3.45 \pm 0.10$ and $3.48 \pm 0.14$ respectively.

Table 2: Anti-inflammatory activity of flavonoids isolated from $L$. inermis.

\begin{tabular}{|c|c|c|c|c|}
\hline \multirow{2}{*}{ Groups } & \multirow{2}{*}{ Treatment } & \multicolumn{3}{|c|}{ Anti inflammatory activity $(\mathrm{cm})(\mathrm{M} \pm \mathrm{SD})$} \\
\hline & & $1 \mathrm{~h}$ & $2 \mathrm{~h}$ & $3 \mathrm{~h}$ \\
\hline I & Inflammatory Control ( $2 \%$ carrageenan) & $3.87 \pm 0.10$ & $3.65 \pm 0.13$ & $3.46 \pm 0.15$ \\
\hline II & Standard (Diclofenac sodium 100 mg/kg) & $3.86 \pm 0.15$ & $3.20 \pm 0.10$ & $3.10 \pm 0.10$ \\
\hline \multirow{5}{*}{ III - VII } & Compound $1(100$ mg/kg) & $3.82 \pm 0.12$ & $3.60 \pm 0.05$ & $3.40 \pm 0.14$ \\
\hline & Compound $2(100$ mg/kg) & $3.80 \pm 0.10$ & $3.42 \pm 0.15$ & $3.29 \pm 0.14$ \\
\hline & Compound 3 (100 mg/kg) & $3.87 \pm 0.15$ & $3.55 \pm 0.10$ & $3.36 \pm 0.12$ \\
\hline & Compound 4 (100 mg/kg) & $3.80 \pm 0.10$ & $3.63 \pm 0.21$ & $3.50 \pm 0.06$ \\
\hline & Compound $\mathbf{5}(100 \mathrm{mg} / \mathrm{kg})$ & $3.87 \pm 0.10$ & $3.70 \pm 0.12$ & $3.54 \pm 0.05$ \\
\hline \multirow{5}{*}{ VIII-XII } & Compound $\mathbf{1}(200$ mg/kg) & $3.86 \pm 0.05$ & $3.57 \pm 0.10$ & $3.38 \pm 0.15$ \\
\hline & Compound $2(200 \mathrm{mg} / \mathrm{kg})$ & $3.87 \pm 0.14$ & $3.35 \pm 0.12$ & $3.17 \pm 0.15$ \\
\hline & Compound $\mathbf{3}$ (200 mg/kg) & $3.90 \pm 0.12$ & $3.50 \pm 0.10$ & $3.32 \pm 0.14$ \\
\hline & Compound 4 (200 mg/kg) & $3.83 \pm 0.06$ & $3.61 \pm 0.12$ & $3.45 \pm 0.10$ \\
\hline & Compound 5 (200 mg/kg) & $3.86 \pm 0.05$ & $3.68 \pm 0.10$ & $3.48 \pm 0.14$ \\
\hline XIII & Methanol Extract (300 mg/kg) & $3.84 \pm 0.12$ & $3.61 \pm 0.15$ & $3.43 \pm 0.15$ \\
\hline
\end{tabular}

\section{CONCLUSION}

To conclude, the present work highlights a new potential source of its occurrence in the leaves of $L$. inermis that are explores an opportunity for five known flavones on the biological activity to compare of crude $\mathrm{MeOH}$ extract. Bioactive substances from this plant were employed to develop drugs for treats inflammation and microbial disease.

\section{REFERENCES}

1. Sivarambabu, S.; Rao, J.M.; Rao, K.V.J. New flavanones from the roots of Flemingia stricta. Indian J Chem. 1979; 17B (1): 85-87.

2. Havsteen B. Flavonoid, a class of natural products of high pharmacological potency. Biochem Pharmacol. 1983; 32:1141-1148.

3. Cragg GM, Newman DJ, Snader KM. Natural products in Drug discovery and development. J Nat Prod. 1997; 60: 52-60.

4. Bauer AW, Kirby WM, Sherries M, Durk M. Antibiotic susceptibility testing by a standard single disc method. Amer J Clin Pathol. 1966; 36 : 493-496.

5. Winter CA, Risley EA, Nuss GW. Carrageenan-induced edema in hind paws of the rat as an assay for anti-inflammatory drugs. Proc Soc Exp Biol Med. 1962; 111: 544-547.

6. Kouadio F, Kanko C, Juge M, Grimaud N, Jean A, Guessan YT, Petit JY. Analgesic and anti-inflammatory activities of an extract from Parkia biglobosa used in traditional medicine in the Ivory Coast. Phytotherapy Research. 2000; 14: 635-637.

7. Harborne JB. Mabry TJ, Mabry H. The flavonoids. New York: Academic press; 1975.
8. Mabry TJ, Markham KR, Thomas MB. The Systematic Identification of Flavonoids. Berlin: Springer-Verlag; 1970.

9. Markham KR. Techniques of Flavonoid Identification. London: Academic Press; 1982.

10. El-Sayed HN, Omara MA, Yousef KA, Farag MT, Mabry J. Kaempferol triosides from Reseda muricata. Phytochernistry. 2001; 57(4): 575-578.

11. Herz W, Govindan SV, Riess-Maurer I, Kreil B, Wagner H, Farkas L, Strelisky J. Isolation and synthesis of two new flavones from Conoclinium coelestinum. Phytochemistry. 1980; 19 (4): 669-672.

12. Hase T, Ohtani K, Kasai R, Yamasaki K, Picheansoonthon C. Revised Structure for Hortensin, A Flavonoid from Millingtonia hortensis. Phytochemistry. 1995; 40: 287-290.

13. Kaneta M. The constituents of Anthraxon hispidus Makino. Fukushima Tech Jr Col Bull. 1971; 7: 40-44.

14. Liu Y, Wanger H, Bauer R. Phenylpropanoids and Flavonoid Glycoside from Lysaionotus pauciflorus. Phytochemistry. 1998; 48: 339-343.

15. Saeidnia S, Gohari AR, Ito M, Kiuchi F, Honda G. Bioactive constituents from Dracocephalum subcapitatum. Lips NyZ Natur forsch. 2005; 60 c: 22-24.

16. Ashraf AE, Nabil AA. Antibacterial coumarins isolated from Launaea resedifolia. Chem of plant raw material. 2006; 1: 65-68.

\section{HOW TO CITE THIS ARTICLE}

Manivannan R., Aeganathan R., Prabakaran K. Anti-microbial and antiinflammatory flavonoid constituents from the leaves of Lawsonia inermis. The Journal of Phytopharmacology 2015;4(4):212-216. 